\title{
EN1 wt Allele
}

National Cancer Institute

\section{Source}

National Cancer Institute. EN1 wt Allele. NCI Thesaurus. Code C114953.

Human EN1 wild-type allele is located in the vicinity of $2 q 14.2$ and is approximately $6 \mathrm{~kb}$ in length. This allele, which encodes homeobox protein engrailed-1, is involved in both embryonic morphogenesis and transcriptional regulation. 